\title{
Experimental Study on the Safety Assessment of Reinforced Concrete Shear Wall Structure with the Correspondence between Damage Image and Index
}

\author{
Suxia Kou, Jianmin Zhang $(\mathbb{D}$, and Jing Ren \\ College of Civil Engineering, Northeast Forestry University, Harbin 150040, China \\ Correspondence should be addressed to Jianmin Zhang; tumuzjm@nefu.edu.cn
}

Received 30 January 2021; Revised 6 April 2021; Accepted 15 May 2021; Published 1 June 2021

Academic Editor: Daniele Baraldi

Copyright (c) 2021 Suxia Kou et al. This is an open access article distributed under the Creative Commons Attribution License, which permits unrestricted use, distribution, and reproduction in any medium, provided the original work is properly cited.

\begin{abstract}
The post-disaster emergency rescue and loss evaluation hinges on the timeliness and accuracy of safety assessment of building structures in quake-hit regions. At present, the damage identification of quake-hit buildings in China is mainly conducted based on the experience of the experts. Such an assessment method will inevitably lead to the differences in identification results because each expert has his/her own subjective understanding of the degree of structural damage. In order to solve this problem, the low cyclic loading test of 7 specimens of shear wall is conducted and the hysteretic curves of seven shear walls are drawn. The failure modes and seismic performance of members under different design parameters (axial compression ratio of shear wall, shear span ratio, form of edge member, reinforcement ratio, stirrup ratio of coupling beam, and span height ratio) are compared. By recording the damage images taken at the controlled displacement under each level of load, the corresponding damage indexes are calculated, and the correspondence between the typical component damages and the damage indexes is discovered. After that, the images are compiled into an atlas. The authors calculate the damage index of the overall structure based on the damage indexes of the components and carries out damage identification of RC shear wall structure with the said damage index.
\end{abstract}

\section{Introduction}

At present, the postseismic damage identification in China is mainly conducted based on the professional knowledge and practical experience of scholars and experts. In 2011, China issued the national standard for the postseismic identification of building safety: Post-earthquake field works-Part 2: Safety assessment of building [1]. The standard specifies the principles and methods for safety identification of buildings in the affected regions of a strong earthquake.

However, a careful and close study of its terms and conditions will reveal the fact that the standard is thronged with macroscopic descriptions of different levels of damages to various types of structural components. For example, beam components sometimes have minor cracks; there might be cracks on concrete shear wall openings (6.2.4 Class 4, safety buildings). The descriptive languages could be understood very differently, and they are too subjective to yield objective safety identification results. According to these principles and methods, the same building may be given different identification conclusions.

For the purpose of solving the differences in the identification caused by the subjective reasons and developing a safety identification method for better quantification of the damage situation [2-4], the author carries out low cyclic loading test on shear wall, records the damage images taken at the controlled displacement under each level of load, and calculates the corresponding damage indexes. Then, the correspondence between the macroscopic damages and the damage indexes is obtained, and the images are compiled into an atlas. The research provides a valuable reference for damage identification in quake-hit regions.

The seismic performance of the ordinary RC shear wall has been tested by many experts at home and abroad [5-10]. Three shear wall specimens with different edge constraints are designed in the test [7], and the low cycle reciprocating 
loading test is carried out. The analysis includes failure form, horizontal bearing capacity, displacement ductility coefficient, strength and stiffness degradation, energy dissipation capacity, and other square surfaces. Nine RC shear wall specimens are designed in the test [8]. Monotonic and low cycle cyclic loading tests are carried out by changing axial compression ratio, stirrup ratio of edge members, concrete strength, and loading mode to observe the change process of damage state and mechanical performance of members. The previous studies $[11,12]$ have a reference for this paper. The purpose of this paper is to record the corresponding damage phenomenon under each stage of loading conditions and find the corresponding relationship between the damage index and the damage phenomenon.

\section{Design of Shear Wall Specimens and Material Performance}

2.1. Specimens. In this experiment, 7 shear wall specimens are designed (on a scale of $1: 2.5$ ) based on an 18-story shear wall structure of a residential area in Harbin. The specimens are constructed in consideration of the influence of the axial compression ratio, the shear span ratio, the edge component form [13], and the reinforcement ratio of the longitudinal reinforcement stirrup. A standard specimen SW1 is designed for comparison with other specimens, as shown in Figure 1. Table 1 lists the design parameters of the specimens.

2.2. Material Performance. The C30 fine stone concrete cubes (average compressive strength: 46.6 MPa and standard compressive strength: $39.1 \mathrm{MPa}$ ) are used in this test. The specimens are made of B12 longitudinal bars (yield strength: $509 \mathrm{MPa}$ and ultimate strength: $637 \mathrm{MPa}$ ), B8 stirrups (yield strength: $438 \mathrm{MPa}$ and ultimate strength: $467 \mathrm{MPa}$ ), and B6 stirrups (yield strength: $511 \mathrm{MPa}$ and ultimate strength: $602 \mathrm{MPa}$ ). The performance tests of the materials are all tested in Northeast Forestry University.

\section{Loading Device and Loading System}

3.1. Vertical Loading Device. The axial pressure is applied on the top of the specimen by $300 \mathrm{~T}$ oil pressure jack. The axial pressure is kept constant by adjusting the pump during loading. The jack is connected with the top reaction frame with a horizontal rolling bearing to ensure that the jack can move smoothly with the specimen during loading. The vertical loads applied on each specimen are shown in Table 2.

3.2. Horizontal Loading Device. The maximum horizontal thrust is determined by the push-over analysis of Abaqus before the test of shear wall specimens, and the 100 T electro-hydraulic servo actuator of Shore Western Company is selected. In addition, the horizontal support steel beam is welded at the floor of the shear wall component to restrict the deformation outside the plane due to the high aspect ratio of some specimens. The loading device is shown in Figure 2, and the material drawing of loading device is shown in Figure 3.
3.3. Loading System. The loading stage of the specimens can be divided into three stages: preloading stage, cracking displacement control stage, and displacement control stage. Preloading stage: take $40 \% \sim 60 \%$ of the axial pressure and repeat load $2 \sim 3$ times to eliminate the internal heterogeneity of the specimens. Crack displacement control stage: $2 \mathrm{~mm}$ is selected as the initial step size for reciprocating loading, and each stage increases $2 \mathrm{~mm}$ until the specimen cracks. Displacement control stage: from the beginning of the specimen cracks, the loading is controlled by the displacement with $3 \mathrm{~mm}$ per shift until the bearing capacity decreases to $85 \%$ or less. Measuring points are shown in Figure 4.

\section{Test Results and Analysis}

4.1. Record of the Damage Phenomenon. The shear wall specimens are smeared with the mortar on one side of the wall and brushed with latex paint to simulate the decorative surface of the actual structures, while the other side is exposed to clear water concrete surface to observe the failure of the concrete surface. The two sides are photographed by a camera to record the damage phenomenon under each stage of loading characteristic displacement. The camera layout is shown in Figure 5.

4.2. Test Phenomena. The final breakdown phenomenon of the seven shear walls is shown in Table 3.

4.3. Shear Wall Hysteresis Curves. Figure 6 illustrates the hysteresis curves of the 7 shear wall specimens of the test.

It can be seen from the above hysteresis curves that each of the specimens has a large stiffness when the displacement is small. In this situation, the specimens can be recovered after unloading because they are still elastic with very small residual deformation. With the increase of the displacement, the components begin to yield and the residual deformation grows. In this case, the specimen can no longer return to the original form, at the same time, more hysteretic energy is consumed. In the later stage of loading, a sharp decline is set in the stiffness and strength of the specimens, and the hysteresis curves are in S-shape with typical pinch effect $[14,15]$.

Comparing the hysteresis curves of SW1 and SW2 specimens, it is observed that the ultimate bearing capacity of the specimens has obviously increased with the axial compression ratio increases, but the ductility has reduced and the energy dissipation capacity of the specimens has weakened. After reaching the maximum bearing capacity, the specimen with larger axial compression ratio experiences faster decline in strength and higher vulnerability to brittle damage.

Comparing the hysteresis curves of SW1, SW3, and SW4 specimens, it can be obtained that the increase in the shear span ratio has caused obvious drop of the bearing capacity, apparent growth in ductility, and prominent increase in energy dissipation capacity of the specimens. The longer yield plateau of the specimens and the trend of flattening give evidence of the enhancement of ductility of the specimens. 

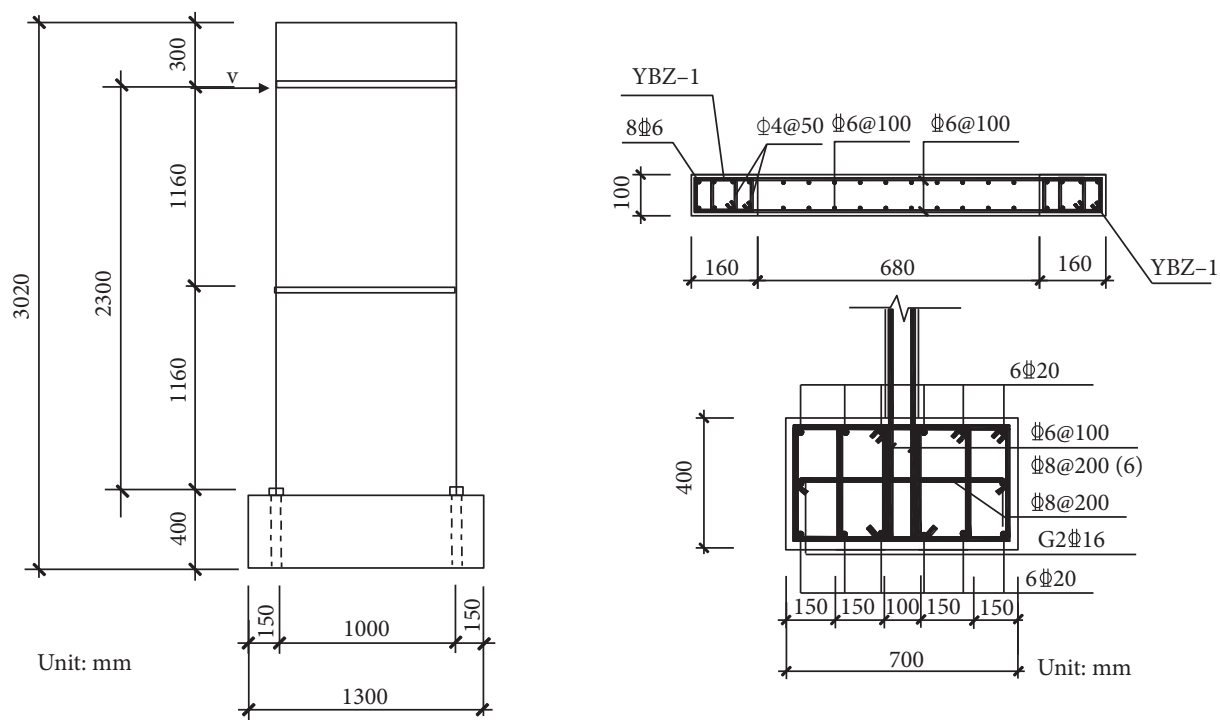

(a)
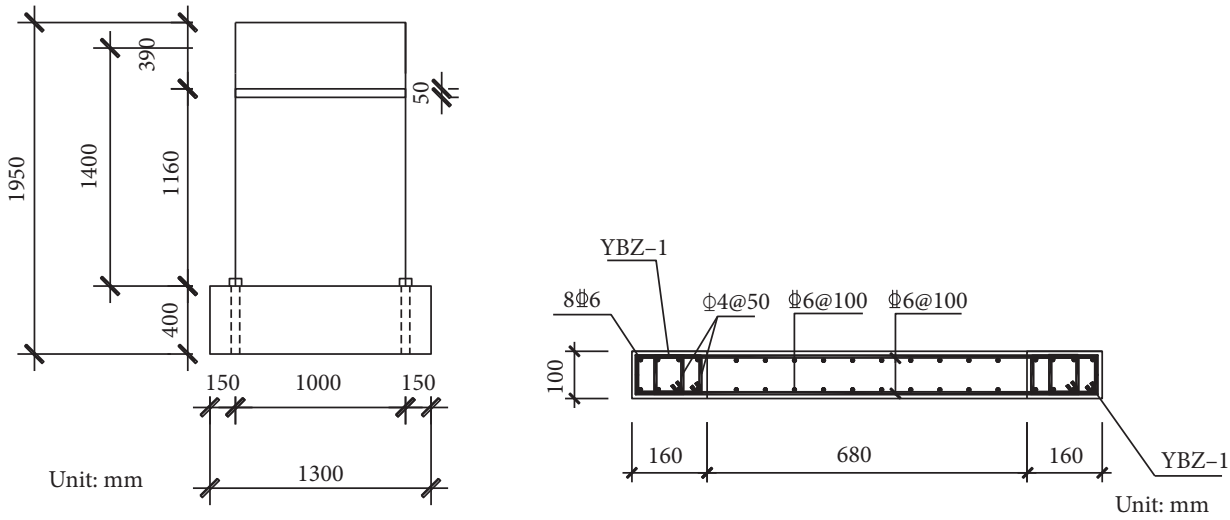

(b)
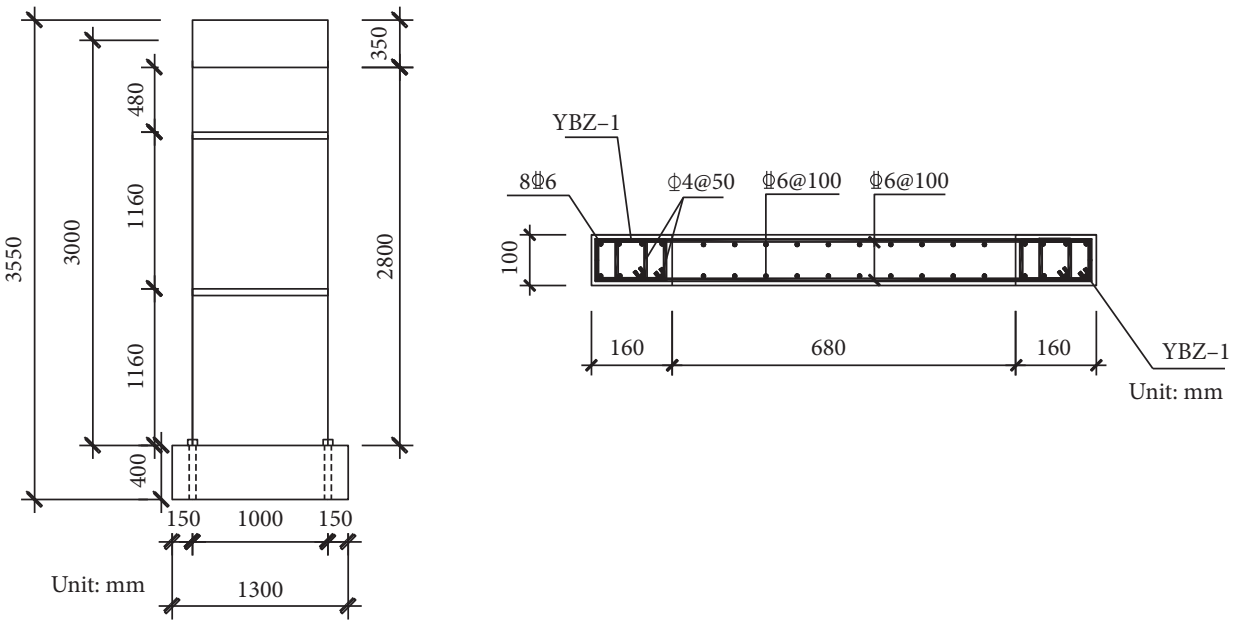

(c)

Figure 1: Continued. 

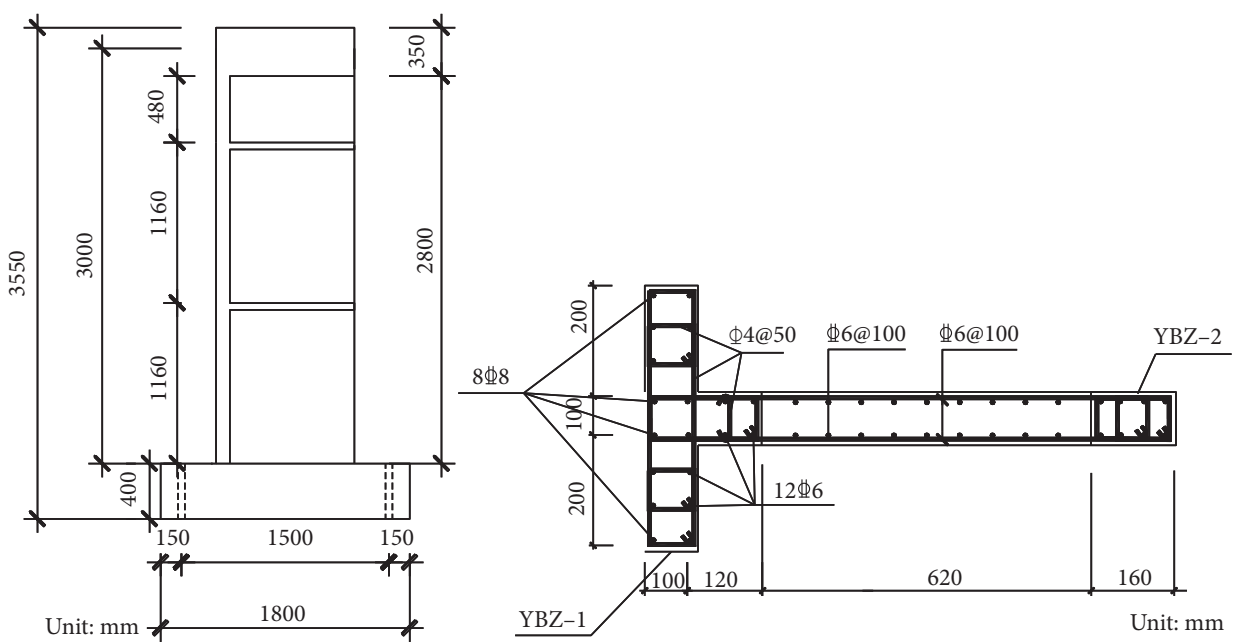

(d)

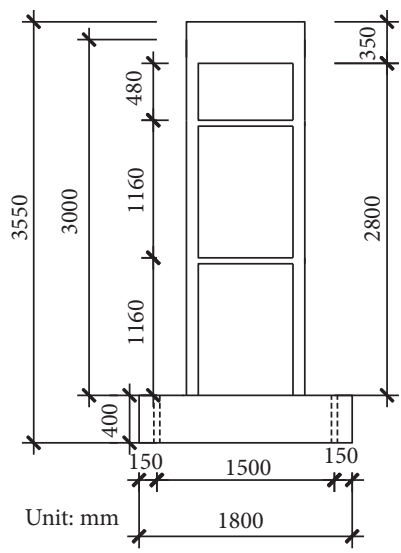

(e)
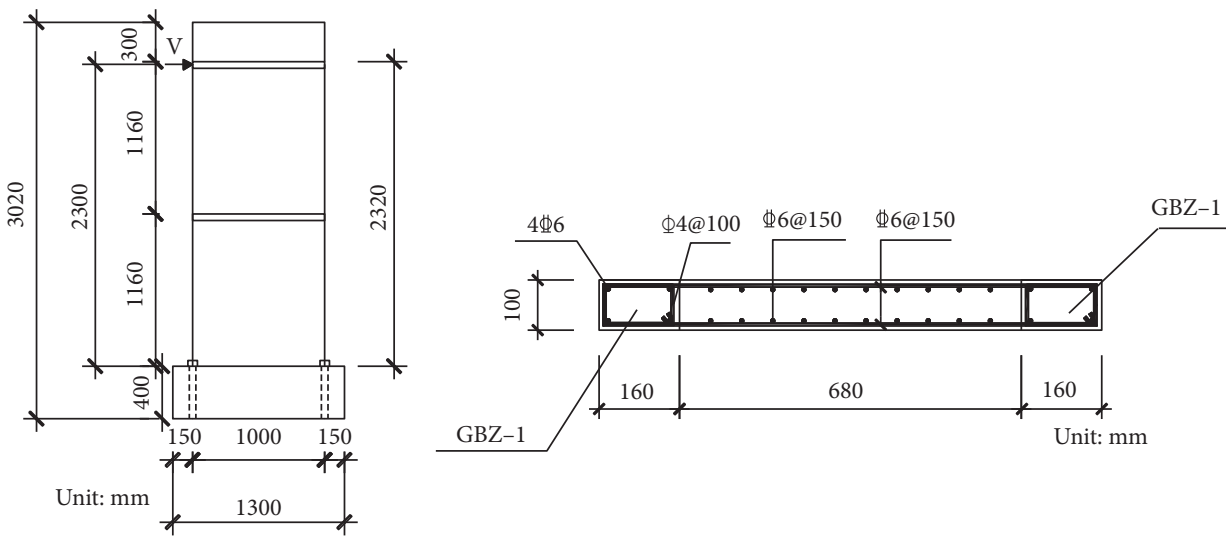

(f)

FIGURE 1: Design of specimens. (a) Design drawing of SW1 and SW2. (b) Design drawing of SW3. (c) Design drawing of SW4. (d) Design drawing of SW5. (e) Design drawing of SW6. (f) Design drawing of SW7.

Comparing the hysteresis curves of SW4, SW5, and SW6, it is known that the specimen SW5, which has a T-shaped sectional design, differs slightly from the specimen SW6, which has a $\mathrm{H}$-shaped sectional design. The analysis of the result is that due to the asymmetry of the SW5 specimen section, the forward failure is mainly concrete crushing, and the reinforcement is not broken. For the reason of the small area of concrete in the compression zone, however, the strength of SW5 decreases faster than SW6 as the concrete is crushed after reaching the maximum bearing capacity. Moreover, the negative bearing capacity of the specimen SW5, which has a T-shaped sectional design, has almost the same with that of the specimen SW4, which has a linear-shaped sectional design. However, the negative ductility of the former specimen is stronger than that of 
TABle 1: Design parameters of the shear wall.

\begin{tabular}{|c|c|c|c|c|c|c|c|}
\hline Specimen no. & SW1 & SW2 & SW3 & SW4 & SW5 & SW6 & SW7 \\
\hline Parameter change & $\begin{array}{l}\text { Standard } \\
\text { specimen }\end{array}$ & $\begin{array}{c}\text { Axial } \\
\text { compression } \\
\text { ratio }\end{array}$ & $\begin{array}{l}\text { Shear span } \\
\text { ratio }\end{array}$ & $\begin{array}{l}\text { Shear span } \\
\text { ratio }\end{array}$ & $\begin{array}{c}\text { Edge } \\
\text { component }\end{array}$ & $\begin{array}{c}\text { Edge } \\
\text { component }\end{array}$ & $\begin{array}{l}\text { Reinforcement } \\
\text { ratio }\end{array}$ \\
\hline Wall width (mm) & 1000 & 1000 & 1000 & 1000 & 1000 & 1000 & 1000 \\
\hline Wall height (mm) & 2300 & 2300 & 1400 & 3000 & 3000 & 3000 & 2300 \\
\hline $\begin{array}{l}\text { Wall thickness } \\
(\mathrm{mm})\end{array}$ & 100 & 100 & 100 & 100 & 100 & 100 & 100 \\
\hline $\begin{array}{l}\text { Axial compression } \\
\text { ratio }\end{array}$ & 0.2 & 0.5 & 0.2 & 0.2 & 0.2 & 0.2 & 0.2 \\
\hline Shear span ratio & 2.3 & 2.3 & 1.4 & 3.0 & 3.0 & 3.0 & 2.3 \\
\hline Edge component & $\begin{array}{l}\text { Embedded } \\
\text { column }\end{array}$ & $\begin{array}{l}\text { Embedded } \\
\text { column }\end{array}$ & $\begin{array}{l}\text { Embedded } \\
\text { column }\end{array}$ & $\begin{array}{l}\text { Embedded } \\
\text { column }\end{array}$ & $\begin{array}{l}\mathrm{T} \text {-shaped } \\
\text { wing wall }\end{array}$ & $\begin{array}{l}\text { H-shaped } \\
\text { wing wall }\end{array}$ & $\begin{array}{l}\text { Embedded } \\
\text { column }\end{array}$ \\
\hline $\begin{array}{l}\text { Longitudinal } \\
\text { distributing bars }\end{array}$ & B6.5@100 & B6.5@100 & B6.5@100 & B6.5@100 & B6.5@100 & B6.5@100 & B6.5@150 \\
\hline $\begin{array}{l}\text { Horizontal } \\
\text { distributing bars }\end{array}$ & B6.5@100 & B6.5@100 & B6.5@100 & B6.5@100 & B6.5@100 & B6.5@100 & B6.5@150 \\
\hline $\begin{array}{l}\text { Edge component } \\
\text { stirrups }\end{array}$ & B4@50 & B4@50 & B4@50 & B4@50 & B4@50 & B4@50 & B4@100 \\
\hline
\end{tabular}

TABLE 2: Value of vertical load.

\begin{tabular}{|c|c|c|c|c|c|c|c|}
\hline Number & SW1 & SW2 & SW3 & SW4 & SW5 & SW6 & SW7 \\
\hline Variable & - & $\begin{array}{l}\text { Axial compression } \\
\text { ratio }\end{array}$ & $\begin{array}{l}\text { Shear span } \\
\text { ratio }\end{array}$ & $\begin{array}{l}\text { Shear span } \\
\text { ratio }\end{array}$ & $\begin{array}{l}\text { Boundary } \\
\text { member }\end{array}$ & $\begin{array}{l}\text { Boundary } \\
\text { member }\end{array}$ & $\begin{array}{l}\text { Reinforcement } \\
\text { ratio }\end{array}$ \\
\hline $\begin{array}{l}\text { Ratio of axial } \\
\text { compression }\end{array}$ & 0.2 & 0.5 & 0.2 & 0.2 & 0.2 & 0.2 & 0.2 \\
\hline Vertical load $(\mathrm{kN})$ & 286.0 & 715.0 & 286.0 & 286.0 & 400.4 & 514.8 & 286.0 \\
\hline
\end{tabular}

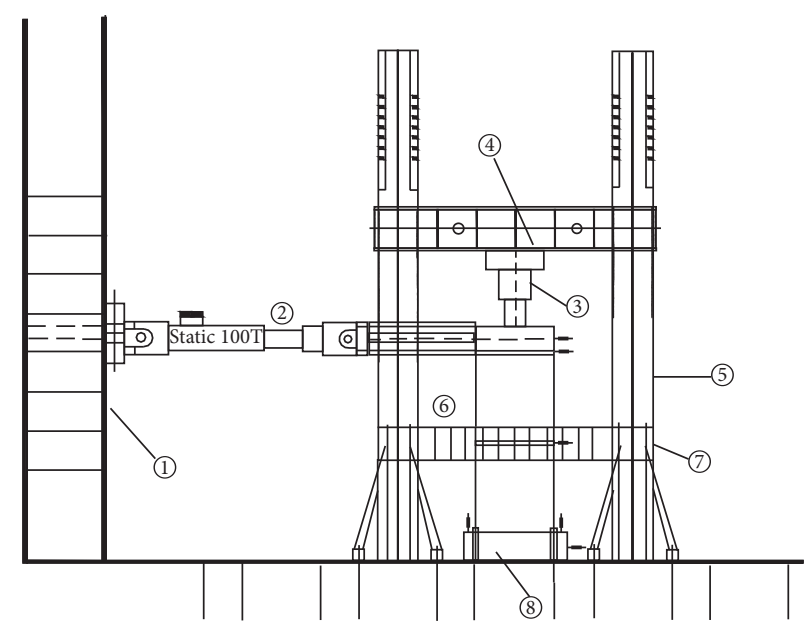

Figure 2: Shear wall loading device. (1) Reaction wall. (2) Actuator. (3) Jack. (4) Roller support. (5) Reaction frame. (6) Shear wall specimen. (7) Lateral confined steel beam. (8) Pedestal.

the latter. The relationship is explained as follows: the concrete of the SW5 is almost uncrushed, thanks to the large area of concrete in the negative compression zone, and the ductility grows with the continuous elongation of bars. At the same time, the SW6, which has a H-shaped sectional design, exceeds the SW4 in both strength and ductility.

Comparing the hysteresis curves of SW 1 and SW7, the bearing capacity of the specimens drops significantly with the decrement of the reinforcement ratio, but the ductility and energy dissipation capacity are greatly strengthened. After reaching the maximum bearing capacity, the specimens with smaller reinforcement ratio experience faster decrement in strength.

4.4. Damage Identification. Referring to the judgment basis of seismic damage of concrete structures in [16] and combining with the classification of damage levels corresponding to damage phenomena of concrete members proposed by Sun 


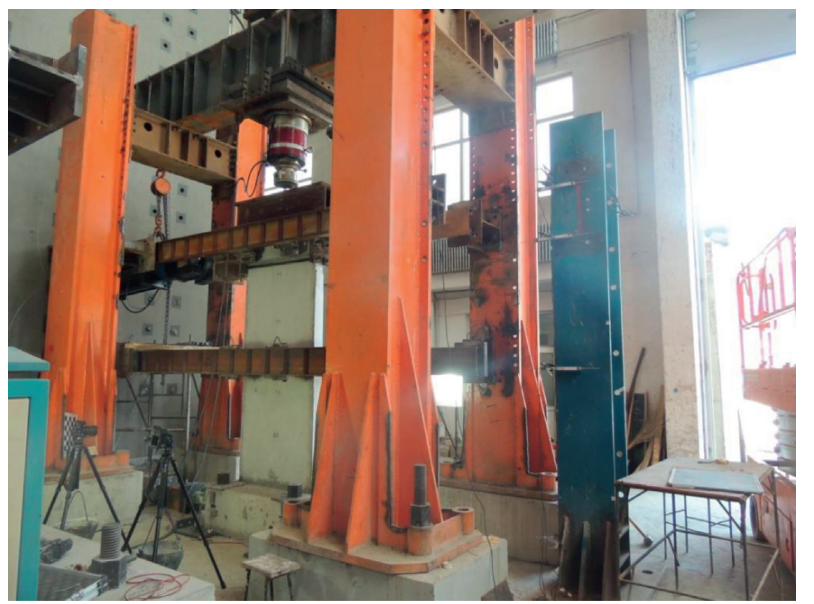

FIgURE 3: Material diagram of shear wall loading device.

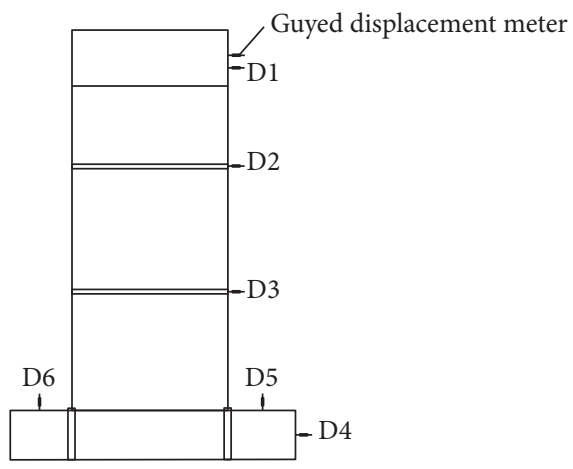

(a)

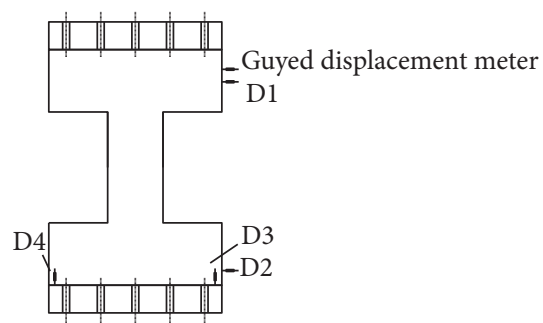

(b)

FIgURE 4: Arrangement of measuring points.
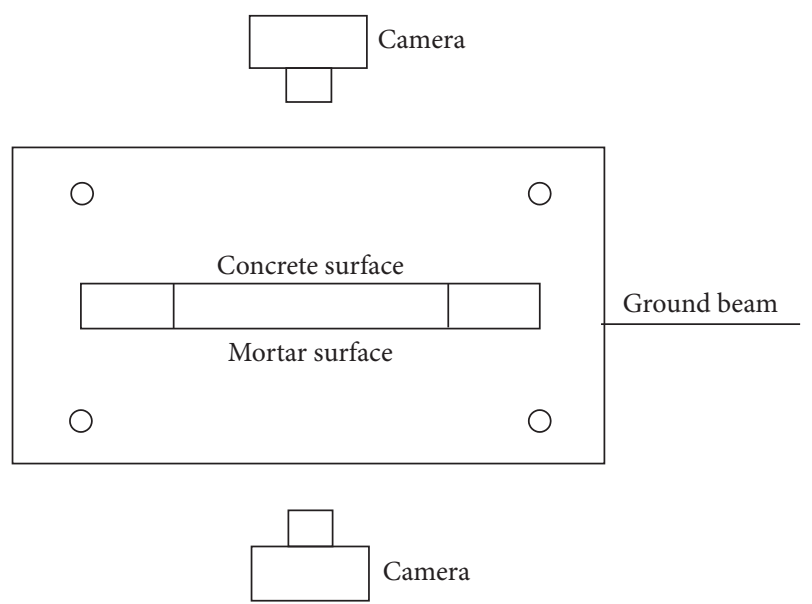

Figure 5: Camera layout of the shear wall.

Baitao, the classification of damage levels of shear wall members based on skeleton curve is proposed in Table 4 .

4.5. Correspondence between Damages and Indexes. In this paper, the modified Park-Ang damage index is taken as the parameter to evaluate the damage degree of the shear wall. Proposed by Y. J. Park and A. H. S. Ang in 1985, the twoparameter failure criterion gives a linear expression of the maximal deformation and cumulative hysteresis energy dissipation of the component. The supported expressions are written as

$$
\begin{aligned}
& D=\frac{\delta_{m}-\delta_{r}}{\delta_{u}-\delta_{r}}+\beta \frac{E_{h}}{Q_{u} \delta_{u}}, \\
& D=\frac{\delta_{m}-\delta_{r}}{\delta_{u 1}-\delta_{r}},
\end{aligned}
$$

where $\delta_{m}$ is the maximum deformation of the specimen under load, $\delta_{r}$ is recoverable deformation (approximated by initial stiffness calculation), $E_{h}$ is the cumulative hysteresis energy dissipation, $\beta$ is the energy dissipation factor (obtained by inverse computation of the test data), $\delta_{u}$ is the displacement when the skeleton curve drops to $85 \%, \delta_{u 1}$ is the limit displacement when the skeleton curve drops to $85 \%$ of the maximum load, and $Q_{u}$ is the ultimate load of the component [17].

According to the above formulas, the damage indexes of the components under each level of controlled displacement are calculated, and these points are marked on the skeleton curve of each specimen. In this way, the correspondence between damages and damage indexes are obtained. Figure 7 shows how the damage indexes correspond to the skeleton curve of SW1. 
TABLE 3: Damage pictures of the seven shear walls.

\begin{tabular}{|c|c|c|c|}
\hline Specimen & Concrete surface damage & Mortar surface damage & Description of damage phenomena \\
\hline SW1 & & & $\begin{array}{l}\text { The mortar falls in large area, and the concrete is crushed so that } \\
\text { some longitudinal reinforcements are exposed }\end{array}$ \\
\hline SW2 & & & $\begin{array}{l}\text { Corner concrete is yielded, and the longitudinal reinforcements } \\
\text { are exposed; specimens' strength decreases significantly }\end{array}$ \\
\hline SW3 & & & $\begin{array}{l}\text { All the corner concrete is crushed and peels off; longitudinal } \\
\text { reinforcements are broken, and the crushing area continues to } \\
\text { develop to the middle of the section }\end{array}$ \\
\hline SW4 & & & $\begin{array}{l}\text { The concrete at the corner dark column is completely compressed } \\
\text { to peel off under the action of repeated load, and the compression } \\
\text { longitudinal reinforcements present a lantern shape }\end{array}$ \\
\hline SW5 & & & $\begin{array}{l}\text { All the concrete at the corner of the compression zone is crushed } \\
\text { and peeled off, and some of the tensile longitudinal bars are } \\
\text { broken; the compressive longitudinal bars are lantern-shaped }\end{array}$ \\
\hline SW6 & & & $\begin{array}{l}\text { Many steel bars are broken and sounded; at this time, the cracks at } \\
\text { the root of the specimen are large and the specimen is staggered } \\
\text { from the root }\end{array}$ \\
\hline SW7 & & & $\begin{array}{l}\text { The concrete is continuously crushed and peeled off, and the } \\
\text { crushed area gradually extends from the corner to the middle of } \\
\text { the section; the tensile reinforcements are broken }\end{array}$ \\
\hline
\end{tabular}

Because of the reason that this test mainly observes the macroscopic failure phenomena of reinforced concrete shear wall specimens (including the failure phenomena of concrete surface and mortar surface) and prepares for the subsequent calculation of damage index and the establishment of the corresponding "damage legend set," the record of test phenomena is particularly important.
By recording the seismic damages caused by the displacement under each level of load from point A to point L, the correspondence between the damage indexes and damages of SW1 is sorted out [18], as shown in Table 5. The correspondence between the damage indexes and damages of every other specimen is not mentioned to keep this paper reasonably concise. 

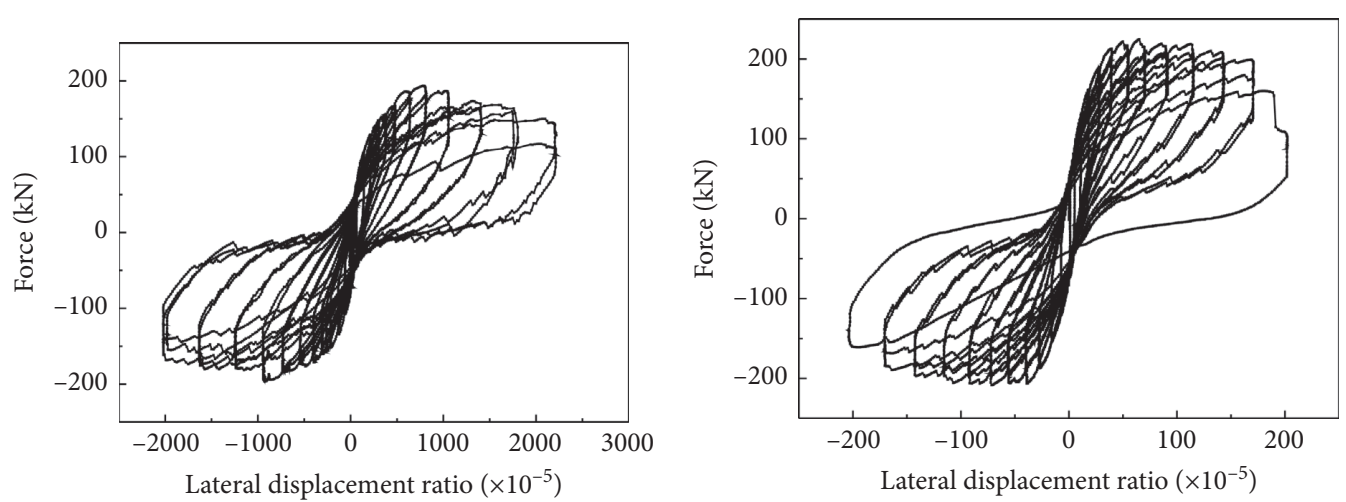

- SW1

- SW2

(a)
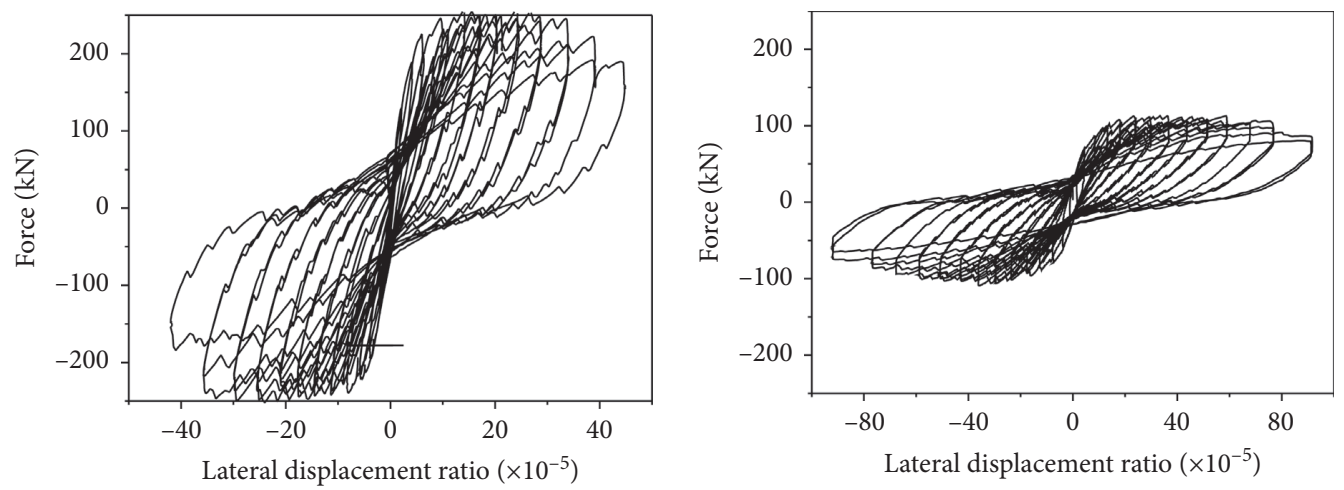

- sW3

(c)

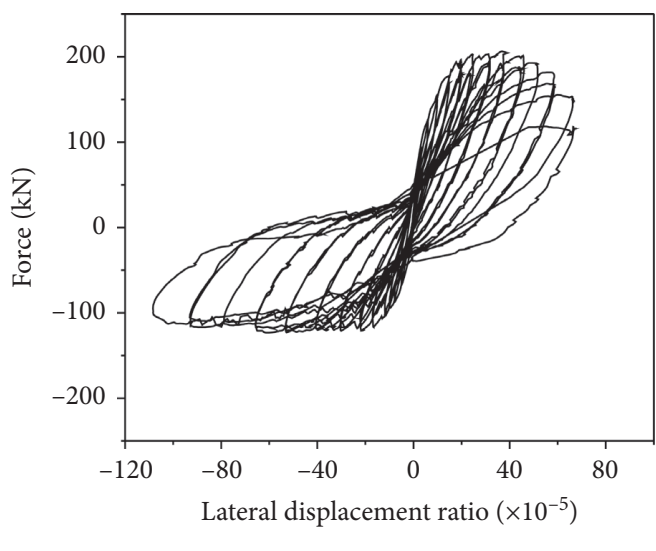

(d)

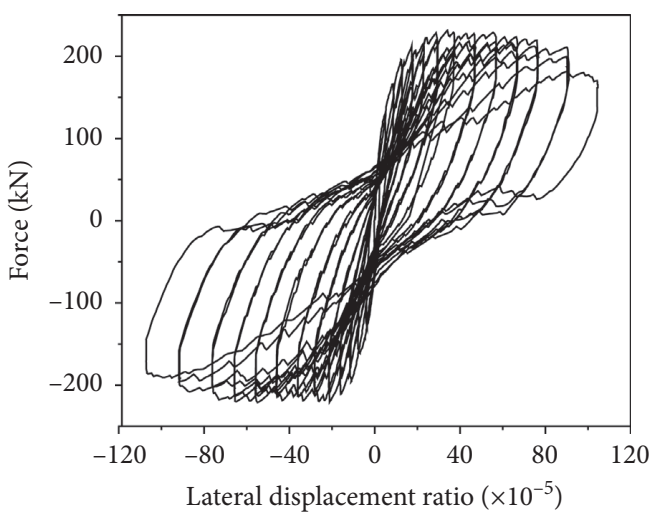

— SW5

(f)

FIgURe 6: Continued. 


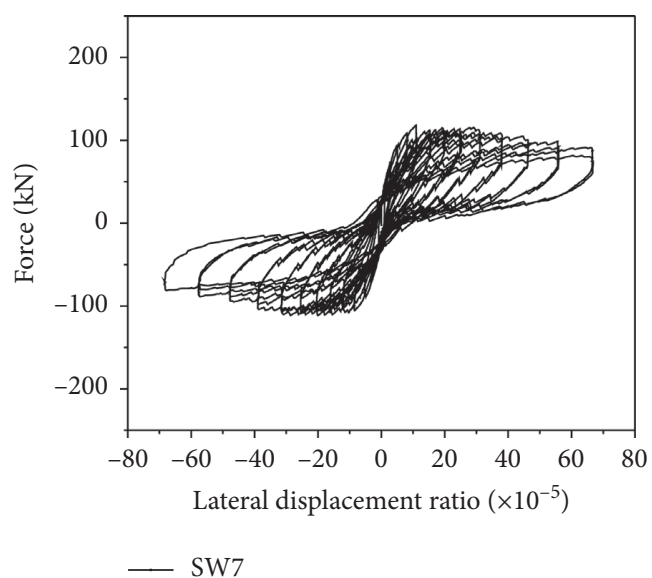

(g)

FIGURE 6: Shear wall hysteresis curves. (a) SW1 hysteresis curves. (b) SW2 hysteresis curves. (c) SW3 hysteresis curves. (d) SW4 hysteresis curves. (e) SW5 hysteresis curves. (f) SW6 hysteresis curves. (g) SW7 hysteresis curves.

TABLE 4: Failure grade of reinforced concrete shear wall members based on skeleton curve.

\begin{tabular}{|c|c|c|}
\hline $\begin{array}{l}\text { Damage } \\
\text { classification }\end{array}$ & Performance of skeleton curve & Note \\
\hline Basically intact & $\begin{array}{l}\text { Straight line, in the bearing capacity rising } \\
\text { section }\end{array}$ & Components are basically in elastic stage \\
\hline Mild & $\begin{array}{c}\text { Bending but still before obvious horizontal } \\
\text { deflection }\end{array}$ & No obvious plastic development of components \\
\hline Moderate & $\begin{array}{l}\text { The decrease of bearing capacity is less than } \\
\qquad 5 \%\end{array}$ & $\begin{array}{l}\text { Ductility such as shear failure and bending failure is poor, and the } \\
\text { skeleton curve is required to be a finite area of failure }\end{array}$ \\
\hline Critical & $\begin{array}{l}\text { The decrease of ductile failure bearing } \\
\text { capacity does not exceed } 15 \%\end{array}$ & The failure limit of ductile failure components is $85 \%$ \\
\hline Failure & Decrease in bearing capacity exceeding limit & $\begin{array}{l}\text { The continued load is in an unstable state, and the whole section concrete } \\
\text { has basically been fully destroyed }\end{array}$ \\
\hline
\end{tabular}

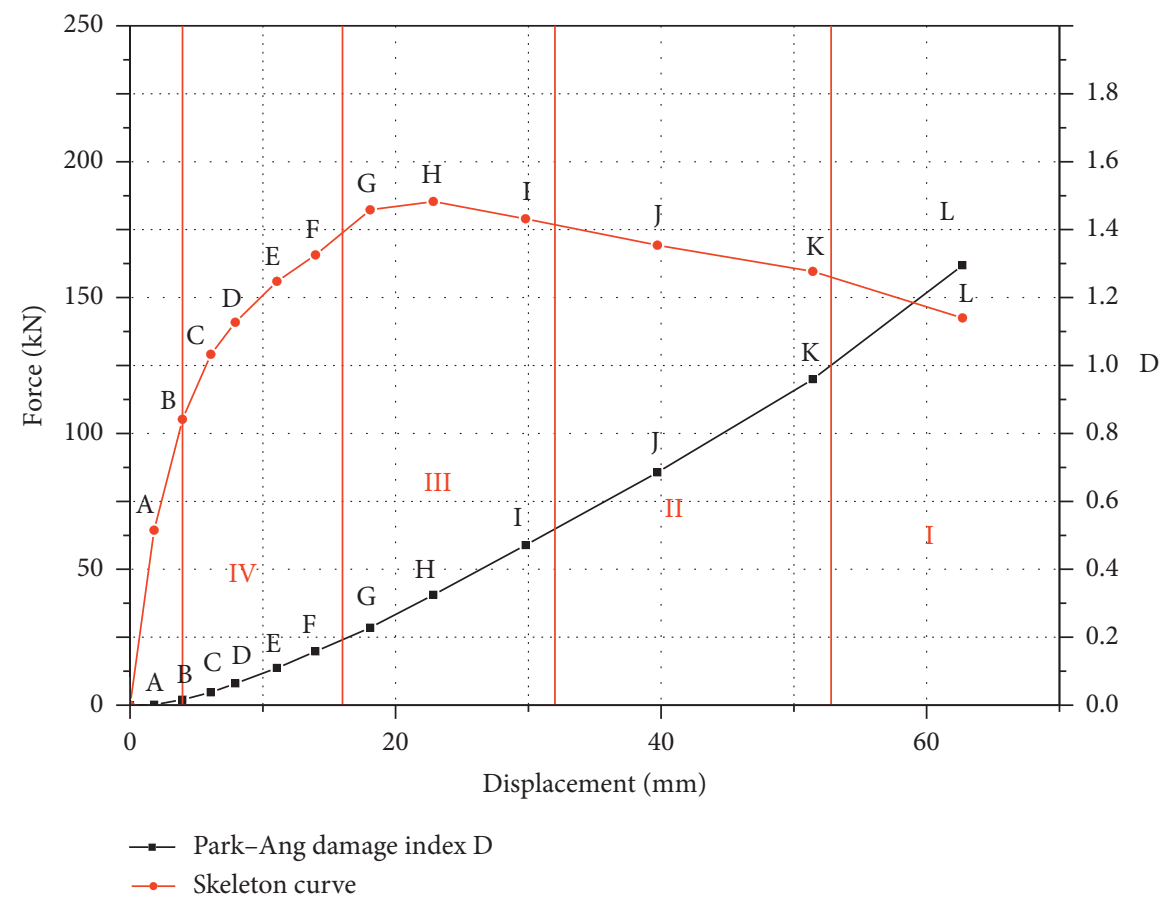

FIGURE 7: The correspondence between the damage indexes and the skeleton curve of SW1. 
TABLE 5: Correspondence between the damages and damage indexes of SW1.

\begin{tabular}{|c|c|c|c|c|c|c|c|}
\hline \multirow[b]{2}{*}{ Point } & \multirow[b]{2}{*}{ Displacement } & \multirow[b]{2}{*}{$\begin{array}{l}\text { Interstory } \\
\text { drift }\end{array}$} & \multirow[b]{2}{*}{$\begin{array}{l}\text { Damage } \\
\text { index }\end{array}$} & \multirow[b]{2}{*}{$\begin{array}{l}\text { Damage } \\
\text { condition }\end{array}$} & \multirow[b]{2}{*}{ Description } & \multicolumn{2}{|c|}{ Damage image } \\
\hline & & & & & & Mortar surface layer & $\begin{array}{c}\text { Concrete surface } \\
\text { layer }\end{array}$ \\
\hline A & \pm 1.81 & $1 / 1270$ & 0.001 & $\begin{array}{c}\text { Basically } \\
\text { intact }\end{array}$ & - & - & - \\
\hline B & \pm 3.95 & $1 / 582$ & 0.016 & $\begin{array}{l}\text { Basically } \\
\text { intact }\end{array}$ & $\begin{array}{c}\text { The roots are slightly cracked but } \\
\text { the cracks disappear after } \\
\text { unloading }\end{array}$ & & \\
\hline $\mathrm{C}$ & \pm 6.08 & $1 / 378$ & 0.037 & $\begin{array}{l}\text { Slight } \\
\text { damage }\end{array}$ & $\begin{array}{l}\text { Horizontal cracks appear, the } \\
\text { mortar begins to get exfoliated } \\
\text { from the concrete, and vertical } \\
\text { cracks appear in the mortar }\end{array}$ & & \\
\hline $\mathrm{D}$ & \pm 7.94 & $1 / 290$ & 0.063 & $\begin{array}{l}\text { Slight } \\
\text { damage }\end{array}$ & $\begin{array}{c}\text { The mortar is significantly } \\
\text { exfoliated, the concrete is slightly } \\
\text { cracked, and the longitudinal bars } \\
\text { are yielded }\end{array}$ & & \\
\hline $\mathrm{E}$ & \pm 11.06 & $1 / 208$ & 0.110 & $\begin{array}{l}\text { Slight } \\
\text { damage }\end{array}$ & $\begin{array}{l}\text { The horizontal main crack } \\
\text { develops to half the height of the } \\
\text { section }\end{array}$ & & \\
\hline $\mathrm{F}$ & \pm 13.98 & $1 / 165$ & 0.158 & $\begin{array}{l}\text { Slight } \\
\text { damage }\end{array}$ & $\begin{array}{l}\text { The concrete in the compressed } \\
\text { zone is slightly crushed, and } \\
\text { vertical cracks appear in the } \\
\text { concrete }\end{array}$ & & \\
\hline G & \pm 18.09 & $1 / 127$ & 0.228 & $\begin{array}{l}\text { Slight } \\
\text { damage }\end{array}$ & $\begin{array}{c}\text { The sound of mortar exfoliation is } \\
\text { heard during the loading process, } \\
\text { and the mortar is crushed } \\
\text { significantly }\end{array}$ & & \\
\hline
\end{tabular}


TABLE 5: Continued.

\begin{tabular}{|c|c|c|c|c|c|c|c|}
\hline \multirow[b]{2}{*}{ Point } & \multirow[b]{2}{*}{ Displacement } & \multirow[b]{2}{*}{$\begin{array}{c}\text { Interstory } \\
\text { drift }\end{array}$} & \multirow[b]{2}{*}{$\begin{array}{l}\text { Damage } \\
\text { index }\end{array}$} & \multirow[b]{2}{*}{$\begin{array}{l}\text { Damage } \\
\text { condition }\end{array}$} & \multirow[b]{2}{*}{ Description } & \multicolumn{2}{|c|}{ Damage image } \\
\hline & & & & & & Mortar surface layer & $\begin{array}{c}\text { Concrete surface } \\
\text { layer }\end{array}$ \\
\hline $\mathrm{H}$ & \pm 22.84 & $1 / 101$ & 0.325 & $\begin{array}{l}\text { Medium } \\
\text { damage }\end{array}$ & $\begin{array}{c}\text { The cracks of the two directions } \\
\text { intersect each other, the concrete } \\
\text { is crushed significantly, and the } \\
\text { side mortar drops off }\end{array}$ & & \\
\hline I & \pm 29.79 & $1 / 77$ & 0.471 & $\begin{array}{l}\text { Medium } \\
\text { damage }\end{array}$ & $\begin{array}{l}\text { The cracks feature even } \\
\text { distribution and oblique } \\
\text { development, the concrete } \\
\text { crushing is intensified, and } \\
\text { vertical cracks appear }\end{array}$ & & \\
\hline $\mathrm{J}$ & \pm 39.73 & $1 / 58$ & 0.685 & $\begin{array}{l}\text { Severe } \\
\text { damage }\end{array}$ & $\begin{array}{l}\text { Large pieces of mortar drop off, } \\
\text { and part of the concrete is } \\
\text { crushed and drops off }\end{array}$ & & \\
\hline $\mathrm{K}$ & \pm 51.42 & $1 / 45$ & 0.960 & $\begin{array}{l}\text { Severe } \\
\text { damage }\end{array}$ & $\begin{array}{c}\text { Large pieces of mortar drop off, } \\
\text { the concrete is severely crushed } \\
\text { and exfoliated, and the } \\
\text { longitudinal bars are partially } \\
\text { exposed }\end{array}$ & & \\
\hline $\mathrm{L}$ & \pm 62.7 & $1 / 37$ & 1.295 & $\begin{array}{c}\text { Total } \\
\text { damage }\end{array}$ & $\begin{array}{c}\text { The concrete at each corner is } \\
\text { completely crushed and drops off, } \\
\text { and all bars are exposed and } \\
\text { yielded }\end{array}$ & & \\
\hline
\end{tabular}

\section{Conclusion}

This paper develops a novel method for postseismic safety identification of RC shear wall based on the Park-Ang damage index. Through the low cyclic loading test of 7 specimens of shear wall, the damage images taken at the controlled displacement under each level of load are recorded, the damage indexes are calculated, and the atlas for the indexes and damages are provided. Besides, the authors compare the damage modes and seismic performance of the components under different design parameters (the shear wall's axial compression ratio, shear span ratio, from edge component, reinforcement ratio, stirrup reinforcement ratio of the coupling beam, and spandepth ratio). The research serves as the basis for the safety identification of the shear walls with different design parameters in quake-hit regions. The conclusions are as follows: 
(1) For the shear wall component, the ductility of each specimen decreases with the increase of the axial compression ratio, but there is an obvious upsurge in bearing capacity; if the shear span ratio grows, the ductility of each specimen will increase obviously, but the bearing capacity will plunge; the specimens experience great improvement of bearing capacity and ductility when the edge component is reinforced. For the coupling beam component, the increase in the span-depth ratio will cause prominent increase in the ductility of the coupling beam and sharp drop in the bearing capacity, while the reduction in stirrup reinforcement ratio will result in obvious decline of the bearing capacity and ductility of the components.

(2) The damages to the mortar surface layer are more significant than those to the concrete surface layer, therefore, are more representative. In the quake-hit regions, researchers should first observe the damages to the mortar surface layer before removing the layer to observe the damages to the concrete surface layer. Besides, most of the damages to the shear wall structure are concentrated in the bottom plastic hinge area. The damage indexes of a specific component can be determined by comparing the seismic damages at the site and the damage images in the atlas.

(3) According to the existing research results and nonlinear time history analysis of shear wall structures, the relationship and calculation model between component damage and overall structure damage will be given in the future. The damage index of the overall structure can be calculated by the damage index of specific components so that the damage level of the overall structure will be obtained. This study will provide technical support for the damage determination of shear wall structure based on the performance index.

\section{Data Availability}

The experiment data used to support the findings of this study are included within the article.

\section{Conflicts of Interest}

The authors declare that they have no conflicts of interest to report regarding the present study.

\section{Acknowledgments}

In the process, this project was supported by the National Natural Science Foundation of China (51208083).

\section{References}

[1] GB18208.2-2001, Seismic Field Work, Section 2: Building Safety Appraisal, China Standard Press, Beijing, China, 2001.

[2] A. S. Moghadam and A. Eskandari, "Post-earthquake quick inspection of damaged buildings in Bam earthquake of 26 December 2003," Journal of Seismology and Earthquake Engineering, vol. 5, no. 4, pp. 81-90, 2004.
[3] S. Anagnostopoulos and M. Moretti, "Post-earthquake emergency assessment of building damage, safety and usability-part 1: technical issues," Soil Dynamics and Earthquake Engineering, vol. 28, no. 3, pp. 223-232, 2008.

[4] D. D'Ayala and E. Speranza, "An integrated procedure for the assessment of seismic vulnerability of historic buildings," in Proceedings of the 12th European Conference on Earthquake Engineering, pp. 561-570, London, UK, January 2002.

[5] J. W. Chen, Y. P. Su, C. Zhang, H. Qi, and H. Chen, "Experimental study on seismic behavior of two-story shear wall with concrete filled steel tube columns and horizontal joints," Journal of Building Structures, vol. 35, no. 3, pp. 93-101, 2014.

[6] Q. X. Shi, B. Wang, P. Wang, and J. Tian, "Comparison and analysis for seismic performance of RC shear wall with flanges under biaxial loading," Journal of Fuzhou University (Natural Science Edition), vol. 41, no. 4, pp. 712-716, 2013.

[7] H. M. Zhang, X. L. Lv, and L. Lu, "Influence of edge restraint on seismic behavior of reinforced concrete shear wall," Earthquake Engineering and Engineering Vibration, vol. 27, no. 1, pp. 92-98, 2007.

[8] S. S. Zheng, P. J. Hou, and L. Li, "Experimental study on seismic damage of RC shear wall," Civil Engineering Journal, vol. 45, no. 2, pp. 51-59, 2012.

[9] K. Beyer, A. Dazio, and M. J. N. Priestley, "Quasi-static cyclic tests of two u-shaped reinforced concrete walls," Journal of Earthquake Engineering, vol. 12, no. 7, pp. 1023-1053, 2008.

[10] Y. Kitada, T. Nishikawa, K. Takiguchi, and K. Maekawa, "Ultimate strength of reinforce concrete shear walls under multi-axes seismic loads," Nuclear Engineering and Design, vol. 237, no. 12-13, pp. 1307-1314, 2007.

[11] A. Furtado, H. Rodrigues, H. Varum, and A. Costa, "Evaluation of different strengthening techniques' efficiency for a soft storey building," European Journal of Environmental and Civil Engineering, vol. 21, no. 4, pp. 371-388, 2017.

[12] H. Rodrigues, A. Furtado, N. Vila-Pouca, H. Varum, and A. R. Barbosa, "Seismic assessment of a school building in Nepal and analysis of retrofitting solutions," International Journal of Civil Engineering, vol. 16, no. 11, pp. 1573-1589, 2018.

[13] Z. G. Gong, X. L. Lv, and S. Z. Ji, "Experimental study on seismic behavior of shear walls with different edge components," Structural Engineer, vol. 22, no. 1, pp. 56-61, 2006.

[14] W. D. Wang, Q. Q. Yang, and H. W. Li, "Hysteresis behavior analysis of composite shear walls based on layered shell elements and fiber beam elements," Journal of Vibration and Shock, vol. 33, no. 16, pp. 142-149, 2014.

[15] W. R. Lv, Q. Li, C. H. Xu, and L. Huang, "Numerical simulation of reinforced block masonry shear wall based on multilayer shell element," Engineering Journal of Wuhan University, vol. 48, no. 3, pp. 350-354, 2015.

[16] X. Chai, "Building safety evaluation system on seismic site based on VB," Master dissertation, China Earthquake Administration, Harbin, China, 2009.

[17] Y. J. Park and A. H. S. Ang, "Mechanistic seismic damage model for reinforced concrete," Journal of Structural Engineering, vol. 111, no. 4, pp. 722-739, 1985.

[18] S. K. Kunnath and A. M. Reinhorn, Lobo RF. IDARC Version 3.0: A Program for the Inelastic Damage Analysis of Reinforced concrete Structures (Report No. NCEER-92-0022), National Center for Earthquake Engineering Research, State University of New York at Buffalo, Buffalo, NY, USA, 1992. 